\title{
How Social Media Marketing
}

\section{Influences Online Purchasing Decision:} Study of the Viral Marketing and Perceived Ease of Use

\author{
Yessy Artanti, Fajar Hari Prasetyo, and Raya Sulistyowati
}

Universitas Negeri Surabaya, Jl. Lidah Wetan, Surabaya (60213)

\section{Abstract}

Social media presents potentially seductive opportunities for new forms of communication and commerce between marketers and consumers. As advertisers typically want to find some way to follow their target audiences, many new media opportunities are presented to advertisers. The purpose of this study examined viral marketing and perceived ease of use influence on online purchasing decisions. This research is a quantitative research using non-probability sampling method with

Corresponding Author:

Yessy Artanti

yessyartanti@unesa.ac.id

Received: 29 January 2019

Accepted: 27 February 2019

Published: 24 March 2019

Publishing services provided by

Knowledge E

(c) Yessy Artanti et al. This article

is distributed under the terms of

the Creative Commons.

Attribution License, which

permits unrestricted use and

redistribution provided that the

original author and source are

credited.

Selection and Peer-review under the responsibility of the $3 r d$ ICEEBA Conference Committee. judgmental sampling technique. Data were collected using questionnaires from 110 respondents. The scale of measurement in this study was done using Likert scale and then analyzed using multiple linear regression. The results show that viral marketing and perceived ease of use have a significant influence on the online purchasing decision.

Keywords: viral marketing, perceived ease of use, social media

\section{Introduction}

Prior to the internet, all players in the economic activities carried out in a way that is still traditional. Start shopping trade or even single item auction activities conducted by face to face, consumers have to buy goods in shops so there is a meeting between sellers and buyers. Business competition is currently very keen to make a challenge for businesses to remain in the competition. The company expects that revenues continue to increase over time, as an effort to increase revenue is very important for the development of a company's business.

In Indonesia based online trading so significantly in recent years and until now the total number of e-commerce in Indonesia reached 26.2 million. 2016 Economic Census conducted the Central Bureau of Statistics, said that the data e-commerce users in Indonesia in the past 10 years, an increase of approximately 17\% (Central Bureau statistics, 2016). In the e-commerce activities of its own, different from the communication 
used in the conventional business. E-commerce is the communication without having to meet in person, because in their own e-commerce activity makes communicating easier. This led to the communication does not have to come face to face directly, but can be through the medium of internet-based communications and also when the Internet has become the lifestyle of each person to perform a communication.

Diffusion or dissemination e-WOM (electronic word of mouth) will be more rapid and wide using the Internet in a network of social media. Social media is simply a media campaign carried out by the community to build relationships and as an intermediary and a place to socialize and eventually social media converted into a place for people to sell, the sale of products or services, and to share information to consumers. Social media can also be interpreted as a means to communicate and share. Examples of social media are now being sought are: Twitter, Facebook, Instagram, Kaskus, Tumblr, and Path.

Social media has become a tool that is easy to share information as well as a discussion in business activities as well as sharing various kinds of information. Social media is an effective medium in making a sale either goods or services. Social media is also seen as a message sender tool chain that will be distributed by others constantly. Chain messages that are referred to as viral marketing and can be used as a media campaign. In Nurlela research and Wiludjeng (2013), viral marketing is an activity or attempt to influence society by harnessing the power of word of mouth through online media, such as email, and social networks (Facebook, twitter, kaskus etc.). According to Swanepoel (2009) viral marketing is a marketing technique to spread the message using social networking. Social media is one of the objects of the use of the online system so that it can influence online purchase decision. Gay et al. (2007) study examined viral marketing has proven to be an effective tool and low cost in the use of online to promote through individual to send an email to friends and colleagues without the involvement of the company, it also can make an influence on online purchasing decisions. Consumers have a role in the success of the company to run its marketing, consumers are not only being targeted marketing but indirectly affected consumers and serve as agents companies in marketing their products through viral marketing in social media, this phenomenon cannot be denied happening in the world of marketing. When a product has value and worth recommended, consumers will voluntarily recommend the product to others in the social media world. This leads to viral marketing in social media can easily occur. In a study Ristania and Jerry Justianto (2013), viral marketing significantly effect and have contributed to the increase in value on online purchase decisions. 
Online purchase decisions is influenced by various factors one of which is through the promotion of the internet is through viral marketing. If a large number of recipients to forward messages to a large number of people, the growth of fast-growing messaging. This strategy is done with the hope of every consumer to get this information to be infected (so customers or advocate) and then can continue to infect other susceptible users. In research and Haenlein Kaplan (2011) dimensions that can be used as a benchmark in viral marketing is messenger, massage, and environment. They will connect the message to potential customers who will use the goods or services offered as well as recommend it to other consumers.

The other factor besides online purchasing decisions, viral marketing in the purchase of an item in an online service that is a perceived ease of use, or a presumption that if we use the terms that will be easy. Purchases and sales in Indonesia also change from purchases directly to stores, are now turning toward online shopping. The presumption or perceived ease of use considered very important in the use of Internet-based technologies on online shop. In the perceived ease of use are not separated from the model of the Technology Acceptance Model (TAM), which is one of the models were built to analyze and understand the factors affecting the acceptance of the use of computer technology.

According to Davis (1989) TAM is a theory of information systems that are designed to explain how users understand and apply an information technology. One of TAM's own original construction which according to Davis (1989) is the perceived ease of use. Davis (1989) in his book also states that the perspective of ease of application (perceived ease of use) is a degree to which a person believes that using a particular system, capable of reducing the effort someone in doing something. Frequency of use and the interaction between users with the system is also able to demonstrate the ease of use. The system is often used to show that the system is better known, is easier to operate and easier to use by users. According to Nasri and Charfeddine (2012) argues that the ease of online site itself is influenced by the perceived usefulness and perceived ease of use. Meanwhile, according to Venkatesh and Davis (2000) in his research divides the indicators perceived ease of use into four, namely: a clear and understandable (individual interaction with the system is clear and easy to understand), does not require a lot of mental effort (do not take much effort to interact with the system), easy to use (the system is easy to use), easy to get the system to do what he/she wants to do (easy to operate the system in line with what people want to do). Meanwhile, according Amijaya (2010, in Suhir, Suyadi and Riadi 2014) perceived ease of use will have an impact on behavior, 


\section{Literature Review}

\subsection{Online consumer behavior}

In this online consumer behavior, there is a difference with conventional consumer behavior. According Suryani (2013: 250) states that the development of internet technology has spawned a generation that has a different behavior compared to the previous generation. Generation $Y$ were born in the internet era is deemed complete the previous generation, the baby boomers and generation $X$. Generation $Y$ is according Pountain and Robbins (2000) is different significantly from the $X$ generation. Solomon (2013) uses the term Generation $Y$ as echo boomers or millennials. Experts generally agree that this generation in terms of age are generally born in the late 1970s to early 1990 s.

The availability of various information media in the lives of Generation $Y$ have a significant impact on information seeking behavior in making purchasing decisions. Generation $Y$ to get a lot of ease in getting information. Various display information about the product is present in the midst of life and they just choose the advertising of goods or services which are the most powerful. Environmental influences greatly to this generation of consumers. TV stations create programs that fit in accordance with the wishes of this segment group.

According to Ferguson (2011), generation $Y$ is more materialistic than previous generations. The desire to live comfortably in an easy way is a common phenomenon that is prevalent in this generation. Blackwell and Mitchell (2003) compared the circumstances that affect both this generation when childhood in England. In Table 1 is described the difference between generation $X$ and $Y$ in the UK.

TABLE 1: Differences between Generation $X$ and Generation $Y$ in the United Kingdom.

\section{Generation X}

Fewer shopping channels, conventional and limited by the hours of shopping

Limited payment model

Influenced by the environment less

materialism, unbalanced income, social class judged by what one does

Accept advertising and marketing information from media traditional

Women are more interested in personal purposes and clothing shop, while men are more interested in shopping for a car and home repair tools

More affected by family tradition (parents)

\section{Generation Y}

Most of shopping and distribution channels are not restricted by shopping hours. Disseminated through newer retail formats

Unlimited payment model and creative

Post-modern culture. Influenced by TV, magazines, the internet about lifestyle

Advertising and marketing information from sources with cable/digital, mobile phones, and e-commerce

Women are more interested in buying a car and home repair tools, while men buy clothes and personal needs

More effected by friends 
Differences generation characteristics as described in Table 1 also have an impact on consumer behavior model differences. Wherein $\mathrm{Y}$ generations are more likely to use online consumption patterns. Online consumer behavior model consists of two parts, namely the factors that influence consumer behavior online and the consumer decision process. The online consumer behavior model according to Cheung (2003) and Turban et al. (2010: 187) can be seen in Figure 1:

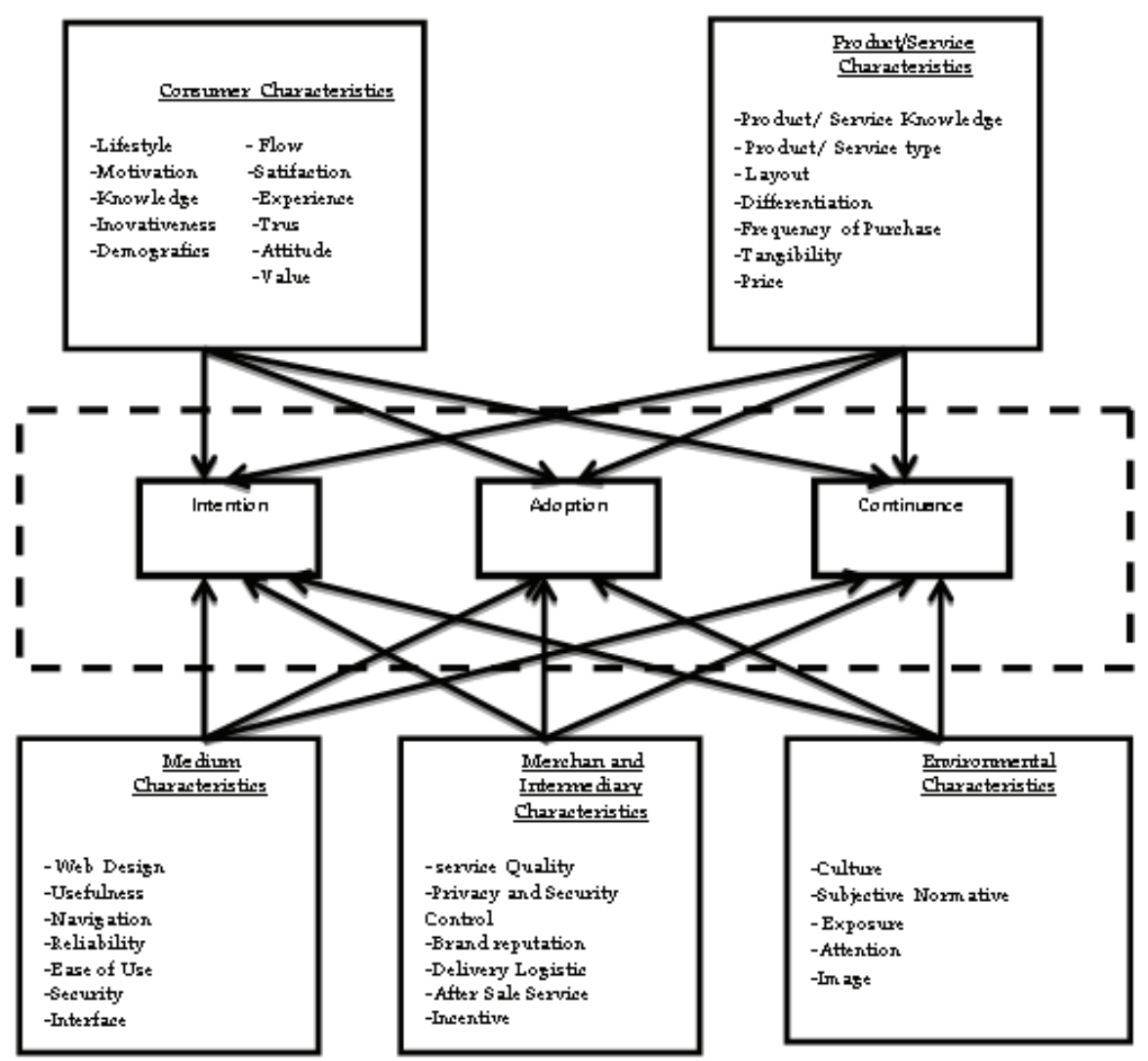

Figure 1: Model of consumer behavior online. Source: Cheung et al. (2003) and Turban (2010: 187).

Model of Fishbein attitude have been widely used in a marketing context. Cheung et al. (2003) examined the factors that explain the intent and the adoption and sustained. In his study explained that the three constructs that that is the intention, adoption, sustained lead to research Turban (2010: 187), which explains that the adoption as well as online purchasing decisions and continuing the same as repeat purchases. From Figure 1 , model of online consumer behavior, there are five important factors that can influence online consumer behavior are: characteristics of the individual/consumer, environmental influences, characteristics of products/services, the characteristics of the medium, as well as marketing and intermediary.

Deavaj et al. (2003, in Anggraeni and Madiawati 2015) said that the purchase decision of an online business is the process of consumer purchases made through the process 
of using the alternative internet-based media have the benefits of further and higher. Lee et al. (2000) describes an online purchase decision is the selection process of combining two or more alternative behaviors and choose one of the strong relationship with personal character, vendors and, attitude at the time of purchase.

\subsection{Viral marketing}

Viral marketing, also known as an electronic word-of-mouth (e-WOM) or "buzz marketing", is the strategy of creating a process where interested people can market to each other (Subramahi \& Rajagopalan, 2003, p.1). In this age of user-generated media, social media is not merely a marketing channel, it facilitates e-WOM. While Web 2.0 media presents communications and sales opportunities for marketers, it brings with it a potential and worrying lack of control of marketing messages. According to Hasan (2010: 42), viral marketing is basically a form of marketing by word of mouth based (eword to mouth marketing) or also called e-WOM marketing functions of promotion are networking and is designed like a virus that spread from one person to others quickly and widely to give special rewards to their customers. Gil-Or (2010) said viral marketing is a phenomenon associated with a message like a virus from one member to the other members within the framework of the network. According to Ehlers, Du Plessis, Strydom, \& Jooste (2012) viral marketing is seen by some as a word-of-mouth advertising where customers tell other customers about products and services. According to (Lekhanya, 2014) identifies viral marketing as a strategy that encourages individuals to pass on a marketing message to others (online sharing), creating the potential for growth in exposure, and influence of the message, it has become an effective way to make a sale without spending many. "Review of some viral marketing theory shows that the desire of consumers to build and strengthen social relationships is determinant to engage in activities to share information. Besides the success of viral marketing can be seen from the individual consumer desires to forward the marketing message to hundreds of other individual consumer. However, Hayes and King (2014) examined only few studies on the role of the social process in which individuals ultimately decide to do activities to online content sharing. Online content sharing has become part of modern life such as submitting an article in the newspaper or magazine, send videos on YouTube, and post a review about a restaurant to a friend. According to Allsop et al. (2007) more than 59\% of the people regularly share online content. 


\subsection{Perceived ease of use}

The other factor besides purchasing decisions online viral marketing in the purchase of an item in an online service that is a perceived ease of use, or a presumption that if we use the terms that will be easy. According to Davis (1989), Theory of Acceptance Model (TAM) is a theory of information systems designed to explain how users understand and apply an information technology on the Internet. TAM's own original construction which, according to Davis (1989) is the perceived ease of use. Davis (1989) argues that the perspective of ease is a degree to which a person believes that using a particular system, can reduce a person's attempt to do something in the world of technology. Frequency of use of the system is also able to demonstrate the ease of use. The system is often used to show that the system is better known, is easier to operate and easier to use. According to Davis (1989), a person's interest in using the technology are affected by attitudes toward these technologies and perceived usefulness. According Wahyuningtyas and Widyastuti (2015) defined perceived ease of use, the extent to which a person believes that using a technology would be free of effort. In the study Pavlou (2003) said that the perceived ease has a positive influence on the willingness to online transact, which shows that the perception of this convenience affect the consumer to decide on online purchasing decisions. The system is often used to show that the system is better known, is easier to operate and to use. The development of the online shop in Indonesia is growing rapidly and quickly. The Ministry of Communications and Information Technology (Kemenkominfo, 2017) describes the Internet users in Indonesia reached 63 million people. Indonesia is one of the countries targeted online store or online shop. It can be seen from the emerging number of online stores or online shopping such as FJB Kaskus, bukalapak, Lazada, Blibli.com, OLX and many."

A wide variety of online stores Indonesia, one of which is Kaskus, a pioneer website because the company itself has stood up dahalu than its competitors. Kaskus is one form of social media in the form of forums on the internet which eventually evolved into one of the sites that apply the concept of e-commerce in Indonesia. Kaskus is different from its competitors website, Kaskus has a discussion forum for users to interact in person to discuss all things desired by the user, and therefore Kaksus different from other websites." 


\subsection{Effect of viral marketing on online purchasing decision}

Consumers will be more interested in a product that has been purchased by friends, family or neighbors. In a study Gay et al. (2007) viral marketing has proven to be an effective tool and low cost in the use of online to promote through individual to send an email to friends and colleagues without the involvement of the company, it also can make an influence on purchasing decisions online. Results of previous studies conducted by Ristania (2013) which states that viral marketing variables have a significant effect and have contributed greatly to the increase in value on the purchase decisions online.

H1: There is significant effect viral marketing on online purchasing decisions.

\subsection{Effect of perceived ease of use on online purchasing decision}

Extensively discusses this relationship, pointing out that in many cases perceived ease of use influence usefulness intention. This is supported by research conducted by Suhir et al. (2014) which states that the ease of use significantly influence online purchasing decisions. The results of the research peneitian Pavlou (2003) said that the perceived ease of use has a positive influence on online transaction intention, which shows that the perception of use affect consumers on online purchasing decisions. Ardyanto (2015) which states that the ease of use significantly influence online purchasing decisions.

H2: There is significant effect perceived ease of use on online purchasing decisions

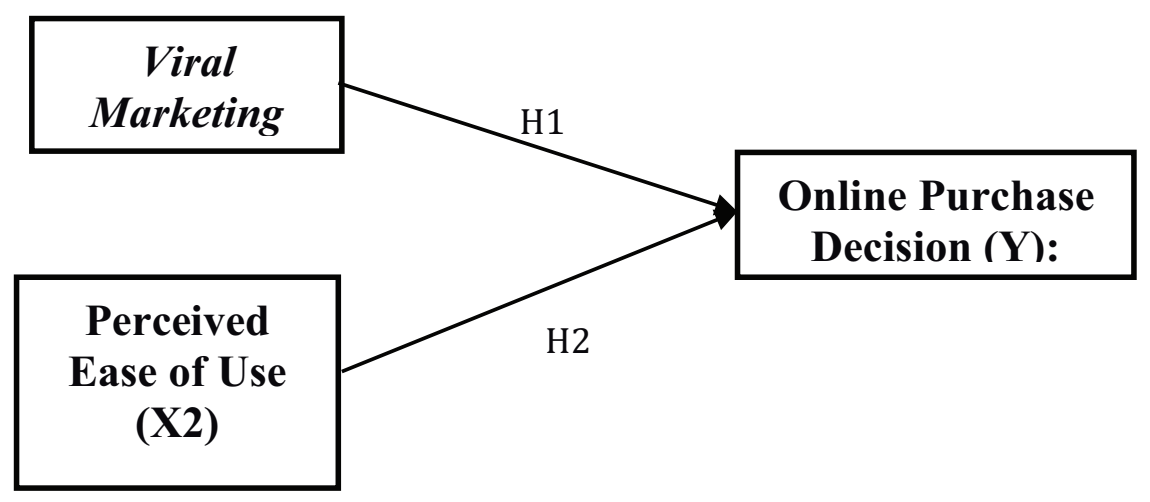

Figure 2: Study design. 


\section{Research Methods}

The samples in this study conducted by online on the webwww.kaskus.co.id especially at trading forums and discussion boards. The study design made this study was to determine whether viral marketing and perceived ease of use influence on online purchase decisions at www.Kaskus.co.id users through the content of the forum. The research model can be seen in Figure 2. This study used a descriptive approach to look for evidence of a causal link between the effect caused by endogenous and exogenous variables at certain phenomena to determine the nature of the relationship between the independent variables and the effect that would be expected. The aim of this study is,to test the hypothesis, so,this research,,a quantitative study. " This study uses the services at Kaskus with two features that exist on a feature Kaskus trading forums and discussion boards. Here is the view 2 features Kaskus forum:

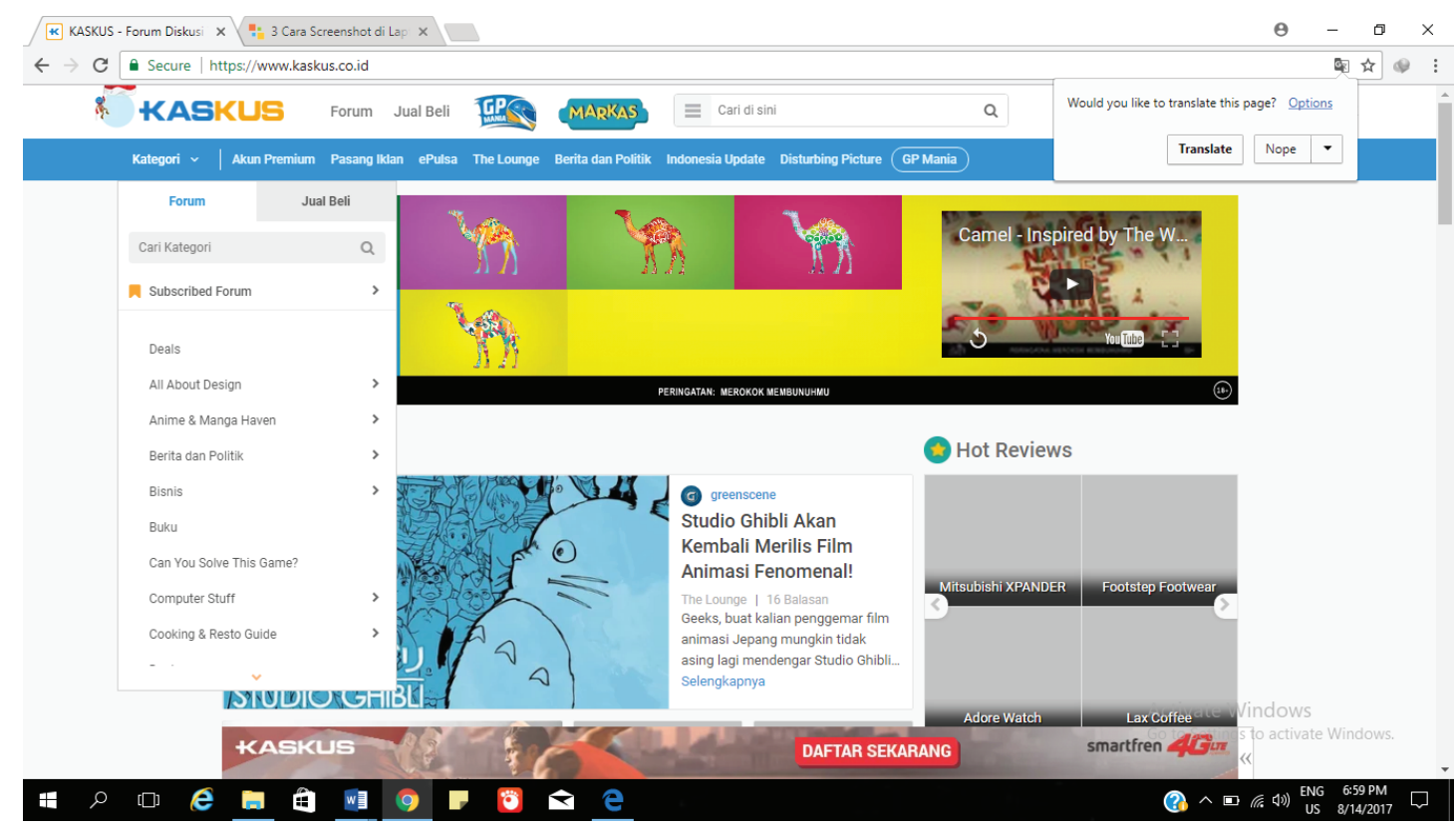

Figure 3: Discussion forum.

Figures 3 and 4 is discussion and trading feature forums where the discussion forum is used for users to exchange information while buying and selling used forum for users to transact the sale and purchase of goods. The population in this study is infinite means that the number of the population studied is not known and the number of sampled, will be the respondent, in this study is,100 respondents, based on the ideas raised by (Ferdinand, 2013: 173) that can be used investigators to determine the sample size in order to obtain a better decision models. researchers determines, a sample size of 100 any, plus $10 \%$ of the total sample (Sarwono, 2008 : 147) so that the total number of samples 


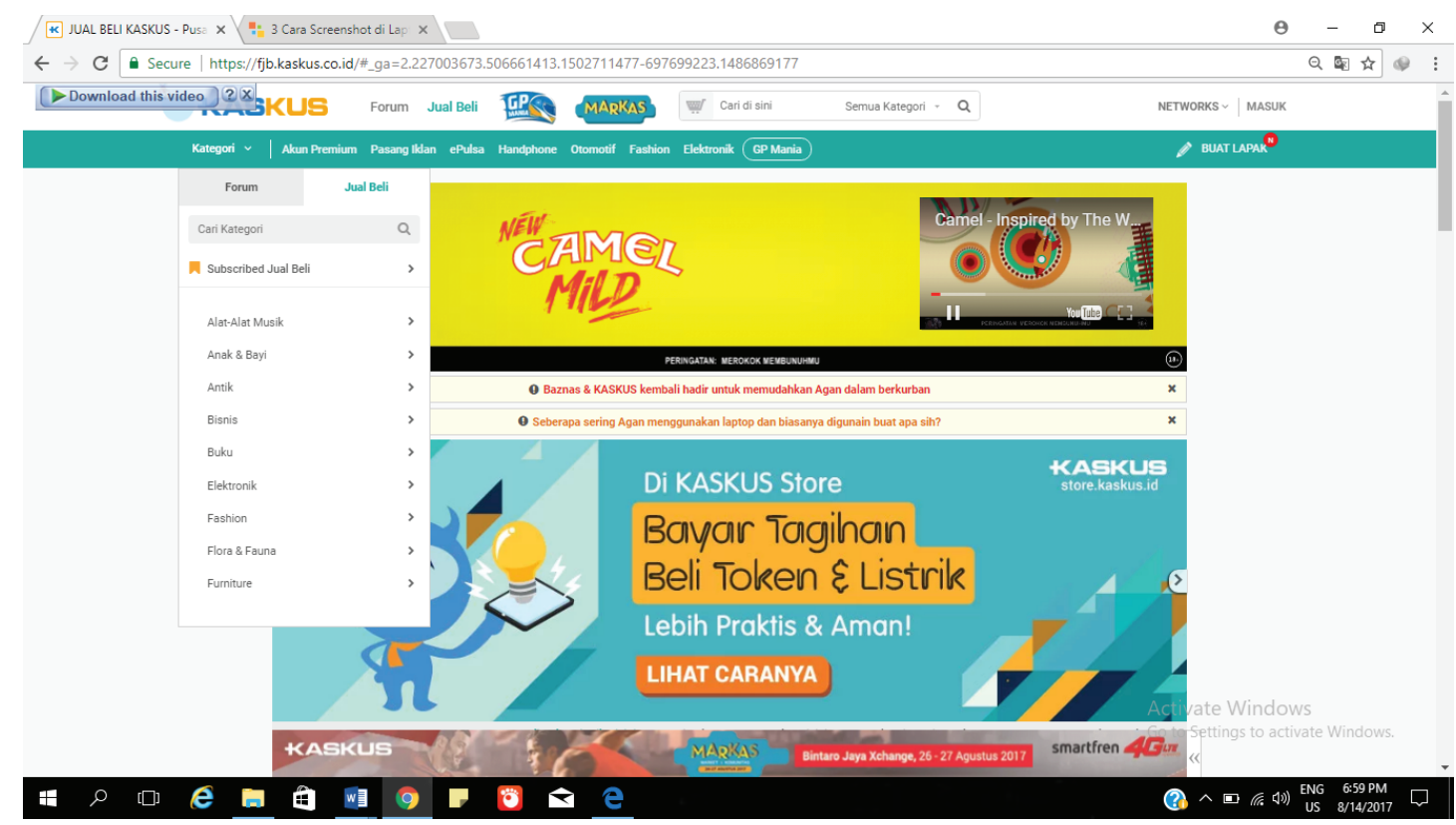

Figure 4: Purchase forum.

to 110 respondents, it is done in anticipation of the invalidity of the item. Measurements of each variable can be described below:

1. Online purchase decision refers to the study Rahmawati (2013) and Nuseir et al. (2010) so that the indicators used are: (1) security, (2) e-pricing, (3) characteristics of products/services, (4) fast in their purchasing decisions, (5) believing that the decision is correct, (6) comfort in interacting, and (7) confidence in buying

2. Viral marketing, using indicators of Kaplan and Haenlein (2011) as an indicator of Ristania and Justianto (2013) more toward factors that predispose people to engage in viral marketing, the indicators used in this study are: (1) messenger (conductor message), (2) message (Message Delivery), and (3) Environment

3. Perceived ease of use in this study refers to Venkantesh and Davis (2000) as an indicator of other researchers majority use indicators that are essentially the same and almost similar to their full. So in this study using 4 indicators, namely: (1) is clear and understandable, (2) does not require a lot of costs, (3) easy to use, and (4) easy to do what they want.

\section{Results and Discussion}




\subsection{Results}

Characteristics of respondents in this study is Kaskus users who have ever made a purchase in trading forum Kaskus total of 110 respondents. The results of questionnaire in the can that: (1) respondents who dominate are male. This is because many men are using Kaskus as a means of discussion as it does in the real world. By using the forum they can exchange information quickly and more open, (2) respondents were mostly 17 25 years, this is because age has a great curiosity. They are willing to try new things and tend to follow the recommendations of others, especially friends, and (3) the majority of the respondents are student.

Prior to the regression test, validity and reliability tests conducted to test feasibility and validity of the items used. Validity test results stating that the entire item statement has Corrected Item-Total Correlation ( $r$ count) greater than $r$ table, so it concluded that the statement - a statement on the research instrument (questionnaire) declared valid and can be used as a measurement for each variable, While the reliability test results can be seen the value of Cronbach's Alpha for viral marketing variables, perceived ease of use and online purchasing decisions is greater than 0.70 . Thus concluded that the statements on the research instrument (questionnaire) is reliable and can be used as a measurement of each variable.

Furthermore, the model used in this study is a model of multiple linear regression analysis. This research data processing using SPSS 23. Before analyzed with regression analysis, it is necessary, the classical assumption in order to give assurance that the regression equation, were found to have accuracy in estimation, unbiased, and consistent "Here is a classic assumption test results will be explained in the drawings and the following table:

Based on Figure 5, "it can be seen on the normal graph plots seen that the points spread around the diagonal line and follow the direction of the diagonal line, these results suggest that the spread of normal distribution of data so that it can be concluded that the regression model used in this study has been to meet the assumptions of normality."

Based on Table 2 shows the value, tolerance on all three variables, greater than 0.379 means that do not occur between variables multicollinearity independent and VIF. The third variable"less than 10 means no, ulticollinearitymulticollinearity occurred between variables independent, can be concluded that the regression model is a regression model is good because it does not have correlation between independent variables. While the significance of the results can be seen that $t$ value not significant because the 


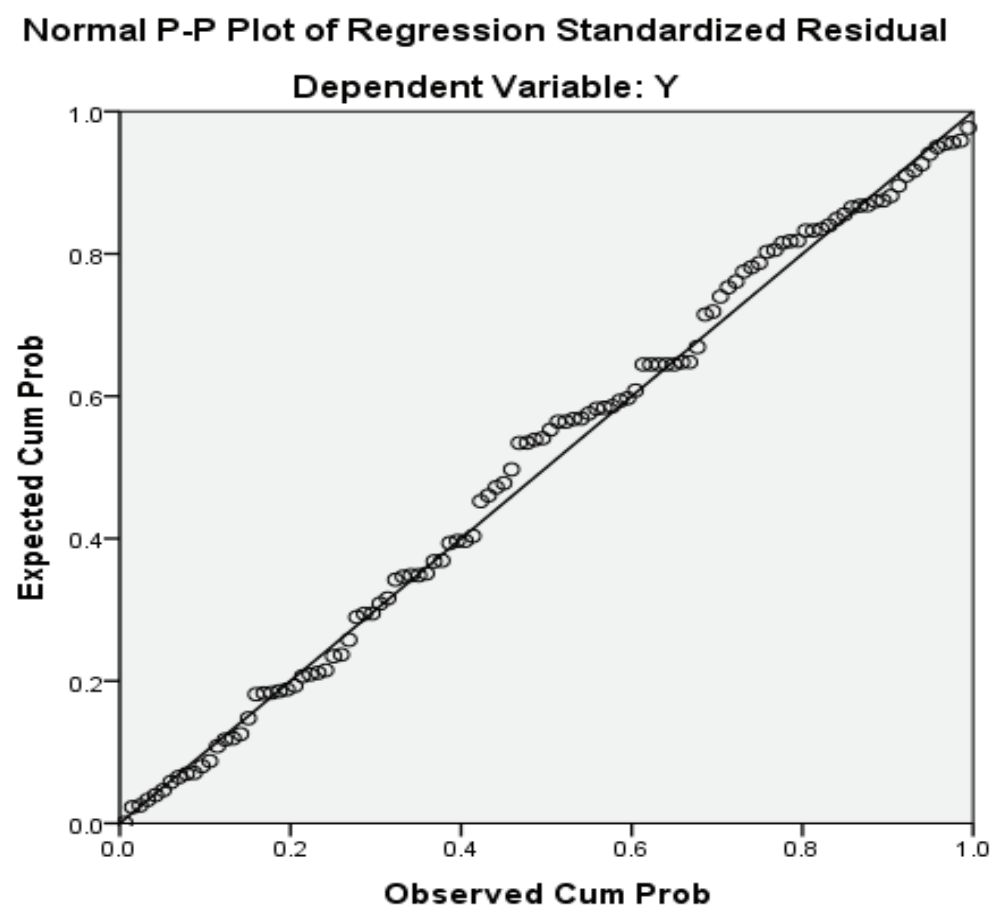

Figure 5: Classic assumption.

TABLE 2: Multicollinearity heteroskedasticities test.

\begin{tabular}{l|c|c|c|}
\hline $\begin{array}{l}\text { Coefficients } \\
\text { Model }\end{array}$ & \multicolumn{3}{c}{ Collinearity Statistics } \\
\hline & Tolerance & VIF & Sig. \\
\hline (Constant) & & & \\
\hline Viral Marketing & 0.379 & 2.637 & 0.283 \\
\hline Perceived ease of use & 0.379 & 2.637 & 0.850 \\
\hline Source: Processed data (2017). & & & \\
\hline
\end{tabular}

significance value of more than 0.05 so that it can be concluded that in our model does not occur heteroskedasticities in viral marketing and perceived ease of use on online purchase decision"

TABLE 3: Multiple linear regression. (Source: Processed data (2017).)

Viral marketing in this study a significant effect because t value"3.349"supported by the sign value. Perceived ease of use in this study a significant effect as $t$-value 4.884 supported by sign value 0.000.",

TABLE 4: Feasibility model. (Source: Processed data (2017).)

Based on Table 4 shows the contribution of independent variables viral marketing (X1) and perceived ease of use (X2) on" online purchase decisions (Y). Adjusted R Square of $0.592=59.2 \%$."From these values indicate that viral marketing $(X 1)$ and perceived ease 
of use (X2) affects online purchasing decisions as much as $59.2 \%$, while the remaining $40.8 \%$ is influenced by other variables outside variables used in this study. "

\section{Discussion}

The results are consistent with the theory according to Hasan (2010: 42) that viral marketing is basically a form of word of mouth marketing based (e-word to mouth marketing) or also called e-WOM. Through viral marketing is good there will be an increase in customers who are followed by increased profits, so that consumers make an online purchase. The results support Justianto (2013) found a significant effect of viral marketing variables and have great contribution to increase the value on online purchasing decisions. Similarly Ristania (2013) which states that viral marketing have a significant effect and have contributed greatly to the increase in value on online purchase decisions. Likewise Gay et al. (2007) said viral marketing has proven to be an effective tool and low cost in the use of online to promote through individual to send an email to friends and colleagues without the involvement of the company, it also can make an influence on online purchasing decisions. In this study viral marketing variables were measured using three indicators, namely: Messenger (shippers), messages and the environment. Indicators Messenger (shippers) is critical of the viral discussion in Kaskus. Seen from the respondents' answers, especially for the statement "The sender of the message (the user) in Kaskus influence someone to forward a message to have the best response because it is people who spread a message mediated social, especially in Kaskus can influence others to recommend resend the message kepengguna another. This shows that the majority of respondents agree that the sender of the message (the user) has a great influence.

As for the effect of perceived ease of use on online purchasing decisions supported Davis (1989) which states that a person's interest to use or adopt a technology is influenced by attitudes to the technology and the perceived usefulness. Components of this technology is considered very important in these findings. The study also supports Widyastuti (2015) that the perceived ease of use as the extent to which a person believes that using a technology would be free of effort. So also supports research Pavlou (2003) says that the perceived ease has a positive influence on the willingness to transact online, which indicates that this convenience affect consumer perception to decide on purchasing decisions online. In addition Wibowo (2006) also stated that the perception of ease of use as a measure of a technology in which a person believes that the technology can be easily understood and used. The results of this study indicate influential 
perceived ease of use because of the ease of technology in social activities or transactions in this case allows consumers who ultimately influence purchasing decisions online. In this study, perceived ease of use of variables measured using four indicators include a clear and understandable, it does not require much cost, easy to use and easy to do what you want.

\section{Conclusion and Implications}

\subsection{Conclusion}

Based on the analysis and discussion of the results of research conducted by the researchers, the conclusions of this research are:"

Conclusion

1. There is a significant positive influence on the decision variable viral marketing online purchases in Kaskus. (Studies www.kaskus.co.id users through the content features of the forum)

2. There is a perceived ease of use of variables influence on purchasing decisions online at Kaskus. (Studies www.kaskus.co.id users through the content features of the forum)

\subsection{Implications of this research}

Web 2.0 social media is a potentially medium for finding key consumer influencers, engaging them, and generating brand advocates. However, in order to build viral campaigns and foster online WOM, perceived ease of use must be established and subsequently reinforced in order to overcome any reluctance on the part of online purchase decision. This means moving beyond "old-school" approaches to website advertising to embrace the principles of relationship marketing - building virtual environments in which customers can connect with each other to share insights and relevant information. One tactic for success is for brands to move away from the hard-sell to instead embrace the notion of "co-creation" by customers. By tapping into or creating their own online social networks, social media marketers can influence a brand community and potentially influence consumer behavior. To capitalize on currently available opportunities, marketers need to find or establish real brand communities, listen to them, and then create special programs and tools that will empower potential and existing community members, rewarding existing consumers and eliciting behavioral change from potential 
consumers. Perhaps advertising effectiveness in the rapidly digitalizing world of television (and other audio and visual media) will be improved through the adoption of synergistic paradigms of co-creation.

\section{References}

[1] Ardyanto, D., Susilo, H., and Riyadi. (2015). Influence: The ease and confidence using the E-commerce against, decision, purchase online. Vol. 22, no. 1, pp. 1-8. Retrieved from: www.petersaysdenim.com

[2] Simamora, B. (2005). Multivariate Analysis of Marketing. General PT Gramedia Pustaka.

[3] Davis, F. D. (1989). Perceived usefulness, perceived ease of, use, and user acceptance of information technology. MIS Quarterly, vol. 13.

[4] Elissa, I. (2013). Analysis of factors affecting buying decision via internet in stores online. Gunadarma University, vol. 8, no. 3, pp. 143-152.

[5] Engel, J. F., et al. (1995). Consumer Behavior, vol. 1, Interpreting Budiyanto. Jakarta: Binarupa Literacy, Jakarta.

[6] Ferdinand. (2013). Research methods management: Pedoma research for thesis and accompanied management science. Diponegoro University.

[7] Ferguson, R. (2008). Word of mouth and viral marketing. Taking the temperature of the hottest trend in,marketing. Journal of Consumer Marketing, vol. 3, no. 2.

[8] Gay, R., et al. (2007). Online Marketing. New York: Oxford University Press Inc.

[9] Ghozali, P. (2013). Applications Multivariate analysis with IBM SPSS Program 21, no. 7. Diponegoro University.

[10] Gil-or, O. (2010). Building consumer demand by using viral marketing tactics within an online social network. Advances in Management, vol. 3, no. 7.

[11] Hasan, A. (2010). Marketing. Yogyakarta: Media Presindo.

[12] Retrieved from: http://apjii.or.id/content (accessed on September 18, 2016; 17:50).

[13] Retrieved from: http://bisniskeuangan.kompas.com (accessed on September 18, 2016; 18:46).

[14] Retrieved from: http://marketeers.com/survey-markplus (accessed on November 6, 2016; 12:09).

[15] Retrieved from: https://kominfo.go.id/index.php/content (accessed on January 8, 2017; 21:00). 
[16] Retrieved from: https://www.bps.go.id/index.php/Brs (accessed on September 15, 2016; 20:31).

[17] Retrieved from: http://www.topbrand-award.com/top-brand-survey/survey result fase2 (accessed on September 20, 2016; 13:55).

[18] Retrieved from: https://www.kaskus.co.id (accessed on November 23, 2016; 23:00).

[19] Katawetawaraks, C. and Wang, C. L. (2011). Online shopper behavior: Influences of online shopping decision. Vol. 1, no. 2, pp. 66-74.

[20] Kotler, P. and Keller, K. L. (2012). Marketing Management (fourteenth edition). USA: Pearson.

[21] Kotler and Armstrong. (2001). Principles of Marketing (eigth edition), vol. 1. Jakarta: Erland.

[22] Kotler and Armstrong. (2009). Marketing Management (thirteenth edition), vol. 1. Jakarta: Erland.

[23] Lekhanya, L. M. (2014). The impact of viral marketing on corporate brand reputation. Vol. 13, no. 2, pp. 213-230.

[24] Lupiyoadi, C. (2013). Services Marketing Management. Jakarta: Four Salemba.

[25] Maholtra, N. K. (2009). Applied Marketing Research Approach (fourth edition), vol. 1. Jakarta: PT index.

[26] Meyer, V., Oliver, B., and Pauli, D. (1998). Multiple developmental requirements of noisette, the Drosophila homologue of the U2 snRNP-associated polypeptide SP3a60. Vol. 18, no. 4, pp. 1835-1843.

[27] Nuseir, M. T., Arora, N., Al-Masri, M. M. A., et al. (2010). Evidence of online shopping: A consumer perspective. International Review of Business Research Papers, vol. 6, no. 5, pp. 90-106.

[28] Rahmawati, S. A. and Widiyanto, I. (2013). Antecedent online purchasing decision. Dipenogoro Journal of Management, vol. 2, no. 3, pp. 1-11.

[29] Saragih, H. and Ramadhany, R. (2012). Effects of intention customers in online shopping returned through media purchase information technology forum kaskus. Journal of Information Systems, vol. 2, no. 2, pp. 113-118.

[30] Sugiyono. (2014). Education Research Methods, Approach Quantitative, Qualitative and $R \& D$. Bandung: Alfa Beta.

[31] Suhari, Y. (2008). Online buying decisions and factors affecting Stikubank University of Semarang. Vol. 8, no. 2, pp. 140-146. 
[32] Suhir, M., Suyadi, I., and Riyadi. (2014). Influence of perception, risk, ease and benefits of buying decision against online (A survey of users of the Site Website www.Kaskus. co.id). Journal of Business Administration, vol. 8, no. 1, pp. 1-10.

[33] Sumarwan, U. (2001). Consumer Behavior Theory and Applicability in Marketing (second edition). Bogor: Publisher Ghalia Indonesia.

[34] Sutedjo, B. (2001). E-business Perspective. Yogyakarta: Adi.

[35] S. P., S. W., and Nurlela, T. S. (2013). Influence buying decision against viral marketing at PT "X". Widyatama University. Vol. 1, no. 1, pp. 978-979.

[36] Swa Magazine. (2016). Indonesia Best Wealth Creator. Issue 15 July-August 32016.

[37] Swanpoel, et al. (2009). Virally inspired: A review of the theory of viral marketing health. Australian Marketing Journal, vol. 17, no. 1.

[38] Wahyuningtyas, Y. F. and Widiastuti, D. A. (2015). Influence analysis of risk perception, ease and benefits of online purchase decision. Journal of Business Research, vol. 23, no. 2 , pp. 112-120.

[39] Venkatesh, V. M., et al. (2003). User acceptance of information technology: Toward a unified view. MIS Quarterly. 